\title{
Prevalence of Periodontal Disease in Patients of Ischemic Heart disease at Bangabandhu Sheikh Mujib Medical University SHOHDA KHATUN ${ }^{1}$, ASHIS KUMAR BISWAS ${ }^{1}$, SOJEEB DHAR ${ }^{1}$, RAJAN KARMAKAR ${ }^{1}$,MD. ABU SIDDIQUE ${ }^{2}$, SAJAL KRISHNA BANERJEE ${ }^{2}$, MD. HARISUL HOQUE ${ }^{2}$, MD. ASHRAF UDDIN SULTAN ${ }^{2}$ \\ ${ }^{1}$ Department of Oral and Maxillofacial Surgery, Bangabandhu Sheikh Mujib Medical University (BSMMU) ${ }^{2}$ Department of Cardiology, Bangabandhu Sheikh Mujib Medical University \\ Address for correspondence: Dr. Shohda Khatun, Senior consultant, Oral \& Maxillofacial Surgery, BSMMU, E-mail: shohdakhatun@yahoo.com
}

\begin{abstract}
The aim of the stuey is to evaluate the association of periodontal condition of patients with Ischemic Heart disease at a university hospital in Bangladesh.

This study was done at Bangabandhu Sheikh Mujib Medical University. Two group of patients was selected. Case group of 25 patients with history ischemic heart disease was selected at OPD of cardiology department another control group 25 patient was selected at dental OPD of BSMMU. Data were analyzed by SPSS, Version 10.

In this study, The mean age $( \pm S D)$ of patients was $50.4 \pm 8.49$ years in the case group and $49.6 \pm 10.9$ years in the control group. 50 patients consisting of 26 males (52\%) and 24 females (48\%) were examined. Study showed that probing depth, plaque index, gingival index, bleeding index, gingival recession and clinical attachment level is more in patient with ischemic heart diseases.
\end{abstract}

This study showed higher incidence and more severe periodontal diseases in patients with ischemic heart diseases.

\section{Introduction:}

Periodontal diseases are one of the most common diseases with an infectious origin resulting in inflammatory destruction of periodontal tissues. These diseases are caused by contact of the periodontium with more than 500 different species of bacteria found in the dental plaque and also by the host response to the bacteria and their product. ${ }^{1}$ Periodontal disease is universal, representing a serious public dental health problem for both developing and industrialized countries. ${ }^{2,3}$

Periodontal disease is the result of periodontal tissue destruction by the action of toxic products released in the sub-gingival area by specific periodontal pathogens. Periodontal diseases can also result from inflammatory and immunological responses caused by the presence of microorganisms and their toxic subproducts (lipopolysaccharides-LPS). ${ }^{4}$

Periodontal conditions can be influenced by some systemic diseases and they also can act as risk factors for some other systemic diseases. ${ }^{5}$ Recent studies ${ }^{6,7-17}$ demonstrate that the association between oral health and atherosclerosis is consistent in different population samples and that the oral conditions precede coronary events. In moderate and advanced cases, the endotoxins (for example, LPS) of the microbial wall can stimulate the accumulation of plaque contributing to the formation of thrombi and atheroma plaque. ${ }^{6,12,18}$ Six studies. ${ }^{19-24}$ have suggested that symptoms of poor oral health and periodontal disease can indicate cardiovascular events.

Since there are few studies regarding oral health in general and periodontal diseases in particular, data relating to distribution and risk factors for these diseases are in short supply. The objective of the present research was to study the prevalence of periodontal diseases in patients with ischemic heart disease

\section{Materials and Methods:}

Study was done at OPD of cardiology department and dental OPD of BSMMU. In the initial stage of the study, the patients were interviewed and examined. During this first contact, data regarding oral conditions were collected and the potential participants of the periodontal investigation were identified. The interviews and oral examination for all candidates were performed by the same dental surgeon. case group and control group were selected. Inclusion criteria was ischemic heart disease patients with periodontal disease in all age and sex. Exclusion criteria was diabetes mellitus, connective tissue disorders, tuberculosis, dyslipidaemia, hyperuricaemia, chronic kidney disease, chronic liver disease and 
hypertension. The patients were periodontally examined and periodontal indices including probing depth (DP), clinical attachment levels (CAL), gingival bleeding (BOP), plaque index (PI), gingival index (GI) and also the total number of lost teeth were all recorded. Clinical attachment level and PD were measured using a Williams's periodontal probe on six regions of each tooth (mesiobuccal, midbuccal, distobuccul, mesiolingual, midlingual and distolingual) and the deepest levels were recorded. Data were analyzed by SPSS, Version 10 . The mean values of PI, BOP, and CAL, PD, gingival recession and number of lost teeth were compared using t-tests.

Figure 4 : The percentages of gingival index in the two groups (case and control).

\section{Results:}

In this study, 50 patients consisting of 26 males (52\%) and 24 females (48\%) were examined. The mean age of the control group patients was 49.6 years and mean age of case group was 50.4 years . In Fig.-1. there were significant differences between the means of all periodontal indices. Fig.-2. showed the percentage of gingival indices in the two groups. Incidence of gingival inflammation is higher in case group (84\%) than control group(68\%). Moderate gingival inflammation was the most common in case group but mild gingival inflammation in the control group. The mean values of plaque index, gingival bleeding, clinical attachment levels, probing depth, gingival recession and number of lost teeth were compared between control group and case group were found highly significant.

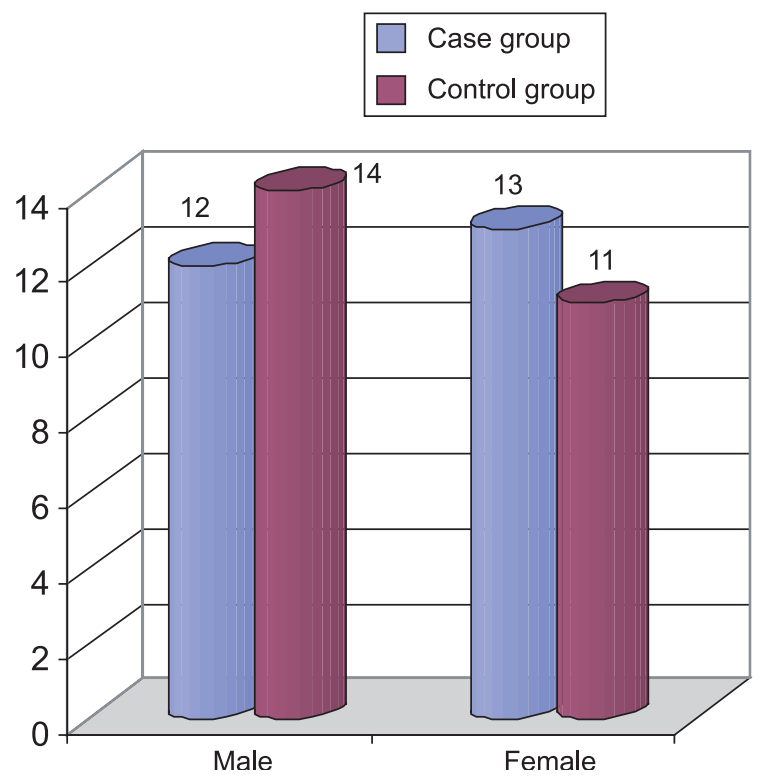

Fig.-1: Distribution of male and female in case group and control group.
Case group

Control group
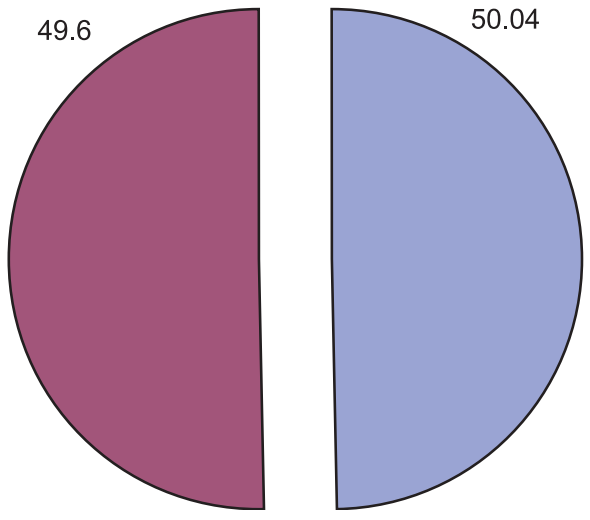

Fig.-2: Mean age

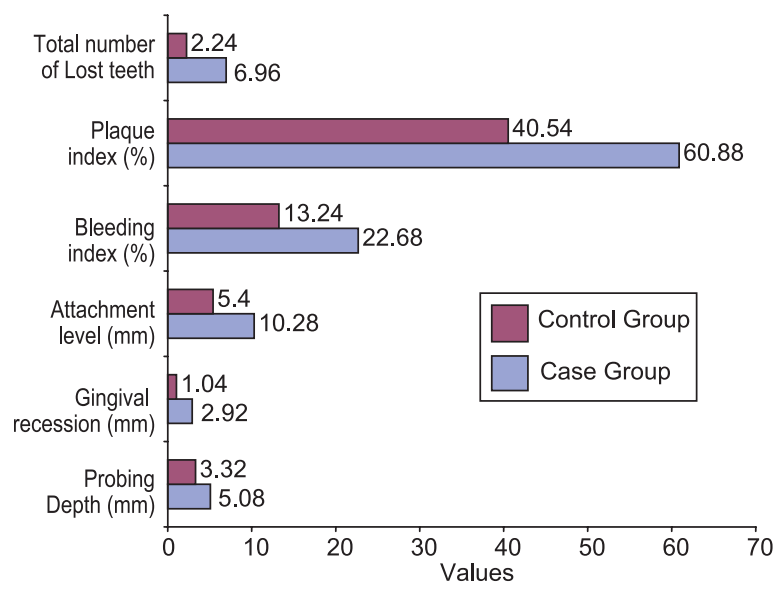

Fig.-3: The means of periodontal indices in the two groups (case and control).

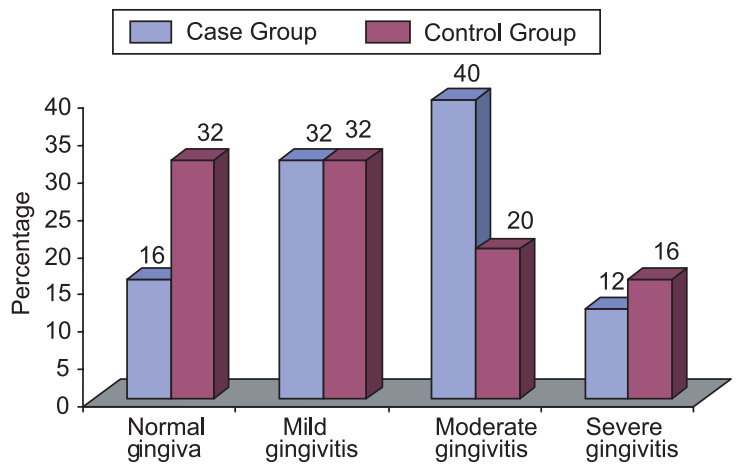

Fig.-4: The percentages of gingival index in the two groups (case and control). 


\section{Discussion:}

In this study control group was selected according to inclusion and exclusion criteria at Dental OPD and history, investigation (ECG, ECO) was used for diagnosis of ischemic heart disease. Clinical attachment level of case group is $10.28 \mathrm{~mm}$ with standard deviation of 1.77 which is much higher than control group (mean 5.4 \& standard deviation 1.5). This result is similar to study of Lopez et al. ${ }^{25}$

In a study by Sadeghi et al., Plaque Index was 57.28\% and $35.37 \%$ in the case group and control group, respectively but in this study plaque index was 40.54 in control group and 60.88 in case group. Periodontal probing depth of case group is 5.08 and 3.32 in control group. This finding is different from the study by Willershausen et al. ${ }^{26}$

In the case group bleeding index is 22.64 but in control group it is 13.24. Sadeghi et al also found bleeding index is higher in case group. ${ }^{27}$ Gingival recession is higher in case group than control group, 2.92 and 1.04 respectively. Total number of tooth loss in case group is 6.96 and in control group is 4.24 .

In this study, apparently normal gingiva is more in control group (32\%) than case group but moderate gingivitis is more in case group (40) than in control group(20\%). Incidence of mild gingivitis is same in both group and severe gingivitis is more in control group than case group.

\section{Conclusion:}

All periodontal , gingival indices and the total number of lost teeth were higher in patient with ischemic heart diseases.

\section{References:}

1. Scannapieco FA.Periodontal disease and cardiovascular disease. Epidemiology and possible mechanisms. J Am Dent Assoc 2002 133:145-225.

2. Loe H, Anerud A, Boysen H, Morrison E. Natural history of periodontal disease in man. Rapid, moderate and no loss of attachment in Sri-Lankan tea laborers 14 to 46 years of age. J Clin Periodontol 1986; 13(5): 431-45.

3. Papapanou PN. Periodontal diseases: epidemiology. Ann Periodontol. 1996; 1(1): 1-36.

4. Listgarten MA. Nature of periodontal disease: pathogenic mechanisms. J Periodontal Res 1987; 22(3): 172-8.

5. Genco R, Offenbacher S, Beck J, Rees T. Cardiovascular diseases and oral infections. In: Rose LF, Genco R, Cohen DW, Mealey BL, eds. Periodontal Medicine. Ontario: BC Decker Inc; 2000. p. 63-82.

6. Loesche WJ, Karapetow F, Pohl A, Kocher T. Plasma lipid and blood glucose in patients with destructive periodontal disease. J Clin Periodontol 2000; 27(8): 537-41.

7. Beck J, Garcia R, Heiss G, Vokonas PS, Offenbacher S. Periodontal disease and cardiovascular disease. J Periodontol 1996; 67(10 Suppl): 1123-37.
8. Beck J. Periodontal implications: older adults. Ann Periodontol 1996; 1(1) 322-57.

9. DeStefano F, Anda RF, Kahn HS, Williamson DF, Russel CM. Dental disease and risk of coronary heart disease and mortality. Br Med J 1993; 306(6879): 688-91.

10. Glurich I, Grossi S, Albini B, et al. Systemic inflammation in cardiovascular and periodontal disease: comparative study. Clin Diagn Lab Immunol 2002; 9(2): 425-32.

11. Genco RJ. Current view of risk factors for periodontal diseases. J Periodontol 1996; 67(Suppl): 1041-9.

12. Herzberg MC, Meyer MW. Dental plaque, platelets, and cardiovascular disease. Ann Periodontol 1998; 3(1) 151-60.

13. Loesche WJ. Periodontal disease: link to cardiovascular disease. Compend Contin Educ Dent 2000; 21(6): 463-6, 468, 470.

14. Mattila KJ, Nieminen MS, Valtonen VV, et al. Association between dental health and acute myocardial infarction. $\mathrm{Br}$ Med J 1989; 298 (6676): 779-81.

15. Mattila KJ, Valtonen VV, Nieminen M, Huttunen JK. Dental infection and the risk of new coronary events: prospective study of patients with documented coronary artery disease. Clin Infect Dis 1995; 20(3): 588-92.

16. Mattila KJ, Valle MS, Nieminen MS, Valtonen VV, Hietaniemi KL. Dental infections and coronary atherosclerosis. Atherosclerosis 1993; 103(2): 205-11.

17. Morrison HI, Ellison LF, Taylor GW. Periodontal disease and risk of fatal coronary heart and cerebrovascular diseases. J Cardiovasc Risk 1999; 6(1): 7-11.

18. Ross R. Atherosclerosis is an inflammatory disease. Am Heart J 1999; 138(5 Pt 2): S419-20.

19. Mattila KJ, Valtonen VV, Nieminen M, Huttunen JK. Dental infection and the risk of new coronary events: prospective study of patients with documented coronary events. Clin Infect Dis 1995;20:588-92

20. DeStafano F, Anda RD, Kahn HS, Williamson DF, Russell CM. Dental disease and risk of coronary heart disease and mortality. Br Med J 1993;306:688-91

21. Joshipura KJ, Rimm EB, Douglass CW, Trichopoulos D, Ascherio A, Willet WC. Poor oral health and coronart heard disease. J Dent Res 1996;75:1631-6

22. Beck JD, Garcia R, Heiss G, Vokonas P, Offenbacher S. Periodontal disease and cardiovascular disease. J Periodontol 1996;67(supplement):1123-37

23. Morrison H, Ellison L, Taylor G. Periodontal disease and risk of fatal coronary heart and cerebrovascular diseases. J Cardiovasc Risk 1999;6(7):7-11

24. Wu T, Trevisan M, Genco RJ, Dorn JP, Falkner KL, Sempos CT. Periodontal disease and risk of cerebrovascular disease: the first National Health and Nutrition Examination Survey and its follow-up study. Arch Intern Med 2000;160:2749-55

25. López R, Oyarzún M, Naranjo C, Cumsille F, Ortiz M, Baelum V. Coronary heart disease and periodontitis - a case control study in Chilean adults. J Clin Periodontol 2002; 29:788.

26. Willershausen B, Krahwinkel T, Valentinis L, Todt M. Correlation between inflammatory periodontal diseases and cardiovascular diseases. Eur J Med Res. 2003; 8:499-504.

27. Czerniuk MR, Górska R, Filipiak KJ, Opolski G. C-reactive protein in patients with coexistent periodontal disease and acute coronary syndromes. J Clin Periodontol. 2006; 33: 415-20. 